\title{
Invited author \\ Adventurous activities, embodiment and nature: Spiritual, sensual and sustainable? Embodying environmental justice
}

\author{
Barbara Humberstone \\ Buckinghamshire New University, United Kingdom
}

\begin{abstract}
This paper examines research on adventurous physical activities in nature from the perspective of the sentient body. Drawing upon ethnographic and autoethnographic research, I examine what has been termed 'peak' happenings or 'flow' which many who practise adventurous activities claim to experience through their whole body when in the 'zone'. I consider the concept of 'edgework', voluntary risk-taking, and insightful mobile and social understanding of the relationships between body, emotions and the elements, where the adventurous activity is experienced and interpreted as oneness with nature or expressed as 'spiritual' not only in high but also low risk nature-based sport. I then consider if and in what ways these knowledges may bring about greater understanding and action in relation to social and environmental justice. I argue that adventurous activities/nature-based sport may provide processes and practices that are alternative or complementary to traditional sporting 'body techniques' or 'body pedagogics'. I suggest that modern embodied adventurous practices in nature challenge dominant narratives of body/mind separation and potentially provide a pedagogic process fostering kinetic empathy. Finally I draw attention to the paradox of (re)-presenting sensorial experiences of sport in nature and ask for consideration on how we interconnect with the environment when we participate in adventureous nature-based sports.
\end{abstract}

Keywords: nature, environmental justice, sentient body

Resumo-“Atividades de aventura, incorporação e natureza: espiritual, sensual e sustentável? Incorporando justiça ambiental." Este artigo analisa pesquisas sobre atividades físicas de aventura na natureza a partir da perspectiva do corpo sensível. Com base em pesquisa etnográfica e auto-etnografia, examino o que tem sido chamado de acontecimentos "pico" ou "fluxo," que muitos dos que afirmam praticar atividades de aventura experimentam através de todo o seu corpo, quando na "zona." Eu considero os conceitos 'edgework ,' tomada voluntária de risco, e compreensão perspicaz móvel e social das relações entre corpo, emoções e os elementos, onde a atividade de aventura é vivida e interpretada como unidade com a natureza ou expressa como 'espiritual' não apenas durante esporte na natureza de alto risco, mas também no de baixo risco. Eu, então, considero se e de que maneira esses conhecimentos podem trazer uma maior compreensão e ação em matéria de justiça social e ambiental. Defendo que atividades de aventura/esporte baseado na natureza podem fornecer processos e práticas que são alternativas ou complementares às 'técnicas corporais' do esporte tradicional ou 'pedagogia do corpo.' Eu sugiro que as práticas modernas aventureiras incorporadas na natureza desafiam narrativas dominantes da separação do corpo/mente e potencialmente fornecer um processo pedagógico promovendo empatia cinética. Finalmente, chamo a atenção para o paradoxo de (re) apresentar experiências sensoriais do desporto na natureza e invoco a reflexão sobre como podemos interligar o meio ambiente quando participando em atividades desportivas de aventura na natureza.

Palavras chaves: natureza, justiça ambiental, corpo sensível

Resumen - “Actividades de aventura, el desarrollo y la naturaleza: espiritual, sensual y sostenible? La incorporación de la justicia ambiental." En este trabajo se examina la investigación sobre las actividades físicas de aventura en la naturaleza desde la perspectiva del cuerpo sensible. Basándose en la investigación etnográfica y autoetnográfico, examino lo que se ha denominado happenings 'pico' o 'flujo', que muchos de los que practican actividades de aventura reclamación a experimentar a través de todo su cuerpo cuando está en la "zona". Considero que el concepto de 'edgework', voluntaria asunción de riesgos, y perspicaz comprensión móvil y social de las relaciones entre el cuerpo, las emociones y los elementos, donde se experimenta y se interpreta como la unidad de la actividad de aventura con la naturaleza o se expresa como "espiritual" no sólo en la escuela sino también bajo riesgo deporte basado en la naturaleza. Entonces considero que si, y de qué manera estos conocimientos pueden llevar a una mayor comprensión y actuación en materia de justicia social y ambiental. Yo sostengo que las actividades de aventura / deporte basado en la naturaleza puede proporcionar procesos y prácticas que sean alternativas o complementarias a las "técnicas del cuerpo" deportivos tradicionales o "pedagogía del cuerpo. Sugiero que las prácticas modernas de aventura consagrados en la naturaleza desafío narrativas dominantes de cuerpo / mente 
separación y potencialmente ofrecen un proceso pedagógico fomentar la empatía cinética. Finalmente llamo la atención sobre la paradoja de la (re) presentación de experiencias sensoriales del deporte en la naturaleza y pido a la consideración de la forma en que se interconectan con el medio ambiente cuando se participa en los deportes de aventura basados en la naturaleza.

Palabras claves: la naturaleza, la justicia ambiental, el cuerpo sensible

\begin{abstract}
"How does the body come to 'know' and what kind of biological changes might occur when learning a skill?" (Downey, 2007: 223)

“...our relationship to each other, space, time and place are mediated by our movement through the material and social world." (Fincham, McGuinness \& Murray, 2010:1)
\end{abstract}

"We are the earth, through the plants and animals that nourish us. We are the rains and the oceans that flow through our veins." (http://www.davidsuzuki.org/about/ declaration/ accessed 28-03-13)

\section{Introduction}

In this paper, I am concerned with the mindfulness of the body in the natural environment when practicing adventurous activity/nature-based sport and how the corporeal body/mind experiences oneness with nature or what is oft times called spirituality. On the one hand, the dominant conceptualisation of voluntary risk-taking is through the notion of edgework (Ling, 1990) where humans 'on the edge', at the boundary of control and chaos, manage their emotions of fear engendered through anticipation or performance. On the other hand, I suggest that this sense of oneness or numinousity is not necessarily fostered through fear, but mindful engagement may be constituted within physical practice in a natural environment. Each may have implications for environmental awareness and action.

Much scholarship concerned with nature-based leisure/ adventurous activities from the disciplines of sport, leisure and tourism that has been concerned broadly with sustainability has highlighted a number of issues including the conflicts of peoples' enjoyment and involvement in nature and how to keep the wilderness area pristine or the wild area protected. Another interest has been the ethical dilemmas in extreme sport (Olivier, 2006). Consequently, this has spawned a wealth of research on leisure and tourism management, arguably largely taking a 'Western' or postindustrial society perspective ${ }^{1}$. In Brazil, Carnicelli-Filho, Schwartz, \& Klein Tahara, (2010) have begun to explore the

\footnotetext{
${ }^{1}$ See special issue of Leisure Studies concerned with Leisure and the Politics of the Environment: Aall, Klepp, Engeset, Skuland and Støa (2011); Stoddart, (2011); Mansfield and Wheaton (2011); Church, and Ravenscroft (2011).
}

part emotions of fear play in participants experience of adventurous activities. Very little scholarship has explored how human beings learn to be in the natural environment through practice in adventurous/ nature-based activities. That is few studies have tried to understand our corporeal and sensual relations with the natural environment when we are engaged through sport in nature or adventurous activities. How might we understand pre-modern engagement with the natural environment, which for the most part is sustainable and maintains a close connection with the elements and the non-human world?

To contextualise this original analysis of sensorial research and connections to social and environmental justice, I begin by highlighting the recent work on embodiment in sport and physical culture and the importance of situating the corporeal, physical practice within time, place and space (elements). Research that draws attention to 'edgework' or voluntary risk taking is next explored. This research together with the notion of 'flow' is then explored in relation to people's involvement in nature-based physical activities to highlight, emotions and sensations experienced, on occasions, by participants. I then consider if and in what ways these knowledges may bring about greater understanding and action in relation to social and environmental justice. Finally, I consider the paradox of representation, how can these feelings be (re)-presented and shared?

\section{Embodiment, sensoria and place}

From the early 90s the neglect of the body was identified as problematic in various disciplines such as sociology (Shilling, 1994) and feminist studies (Grosz and Probyn, 1995), and later in sociology of physical culture and sport (Denison \& Markula, 2003; Sparkes, 2002, 2004, 2009, 2010), and tourism studies (Swain, 2004). This observation promoted a revival of attention to the body in sociological research, particularly on sporting embodiment and embodiment in physical culture. Initially in sport and physical culture the theoretical focus tended to be rather abstract, neglecting the actual corporeality and experiential process of engaging in physical activity. However, corporeality and embodiment are now emerging as a substantial area of research in sport and physical culture where sensory features and phenomenological perspectives are explored in a variety of ways (AllenCollinson, (2011); Allen-Collinson and Hockey (2011); Hockey (2006), Hockey and Allen-Collinson (2007). Sparkes and Smith (2012: 170) highlight this 'future shift towards 
more sensuous forms of scholarship in sport and physical culture.' An example of such emerging research is Downey's (2005) (auto)ethnographic research ${ }^{2}$ within the Brazilian sporting cultures, Capoeira. His research explores the sensory lived experiences where Downey, the apprentice performer, learns through practices which involve using all the senses which provide for processes of meaning making whilst embodying understanding. Only recently, however, is this focus beginning to emerge in nature-based physical cultures or adventurous activities; for example (auto) ethnographic research studies in embodiment and windsurfing (Humberstone, 2010, 2011); the body and sensoria in sub-aqua diving (Merchant, 2011); surfing bodies and masculinity (Evers, 2004, 2009). Evers' study typifies the significance and complexity of autoethnographic narrative in understanding affective embodiment and the social.

A significant dimension missing from many studies is the way in which place/space and context influence affects/ emotions-that is the ways in which the body learns to 'know' from its environment. For nature-based sport or adventurous activities or physical cultures the context or environment or place in which the activity takes place is significant for a variety of reasons which will be discussed later in this paper.

Central to analysis of physical culture in nature is making sense of the embodiment, senses, and practice-in-nature nexus (Humberstone, 2011; Fox \& Humberstone, in press). A useful way of considering this theoretically is through the recent thinking of cultural geographers and their notion of 'mobile methodologies.' For as Fincham et al. maintain 'our relationship to each other, space, time and place are mediated by our movement through the material and social world.' (Fincham et al. 2011: 1 my emphasis). Through taking seriously the physical movement or practice in the environment we can begin to conceptualise a more fluid sport embodiment which is situated in time, place and space. The physical adventurous practice is thus contextualised and not isolated. I now consider this conceptualisation and how it might be developed to provide an understanding of the body/mind/ physical practice in nature nexus /junction.

Thrift, (2000), Cresswell, (2006), Urry, (2007), and Fincham et al. (2011) all pay attention to the ways in which movement in general influences the ways in which individuals perceive

\footnotetext{
2 'Reed-Danahay (1997) argues that autoethnography researchers may lay varying emphases on its three inter-related constituents: auto (the self), ethnos(the culture) and graphy (the research process), through the researcher's affective self-story relations between personal experience, life-worlds and engagements with the culture may unfold.' There has been a significant turn to interpretative, phenomenological and narrative methodology in sport and physical culture research during the last decade or so. I do not intend to discuss this shift here. Suffice to say that studies referenced in this text provide examples, discussions and implications of this methodology. I do not intend to rehearse autoethnographic methodologies and associated issues and methods. This is provided elsewhere (see Humberstone 2011).
}

and make sense of their social and material worlds and the ways in which movement through social and material world affects human relations, space, time and place. This concern, for the most part, is largely focused upon urban and familiar contexts. I am suggesting that it is important for a number of reasons that we attend to the contexts, places and spaces, within in which humans practice nature based sport or adventurous activities. The cultural geographers referred to earlier promote a turn to 'mobile methodologies' in research which takes seriously movement through space and time. I would argue that this is similar to many ethnographic approaches which afford significance to 'being there' to data collection but which also takes account of bodily movement through place and space. This attention to being there in nature and the corporeal, sensual experience of nature based sport is central to how we make sense of adventurous activities and our relations with the human and non-human worlds in which these practices in nature take place. As early as 1990s, cultural geographer Rodaway (1994: 4 italics in original) sought 'to offer a more integrated view of the role of the senses in geographical understanding the senses both as a relationship to the world and the senses as themselves a kind of structuring of space and defining place.' More recently Thrift (2006) emphasises understanding space through the affective and senses. I suggest that adventurous activities and nature based sport scholarship can be enriched by engaging with scholarship in the mobile methodology genre and the developing interdisciplinary scholarship concerned with ethnography of the senses.

A recent example of research into adventurous activity which pays attention to physical and sensual engagement with space is Merchant's (2011) research into learning to scuba diving. The significance of attending to the senses in understanding the ways in which individuals and groups come to understand and make sense of their physical practice in the underwater seascape, in the natural environment is evident from her auto-ethnographic study in which she is a participant observer. Whilst drawing empirically from ethnographic methodology, theoretically she takes her direction from the wealth of inter-disciplinary scholarship including phenomenology of perception (Merleau-Ponty, 2002), sensoria scholarship, the anthropology of the senses (in particular Pink, 2009). She affirms that:

The sensorium is the sum of a person's perceptions, or 'the seat of sensation,' of their interpretation of an environment. The different 'ratios of sense' that make up the sensuous and perceptual means by which we come to understand and dwell in space are said to be dependent on shared cultural norms and consequently vary according to social context and geographical location (Howes, 1991). Merchant (2011: 57)

I would suggest that whilst the sociology of adventurous nature-based research in many cases takes seriously the social and natural environment in which it is practiced and learning takes place, there are still few examples of research 
in which the complex relationships through which the body 'learns' to be in the natural environment, how it 'embodies' nature and how or if environmental awareness becomes embodied. The notion of embodiment has recently become revisioned to take account not only of 'body and body work,' but also the location/ situatedness of the knowing body. This provides for the development of understanding and analysis of the contexts in which the adventure practices take place. For Howes (2005:7) embodiment implies an integration of body-mind situating the embodiment in time and space and is suggestive of the sensuous interrelationship of body-mind-environment. We have shown elsewhere that movement in nature, on occasion, may correspond to the interrelationship of body-mind, senses and environment in mindfulness (Fox \& Humberstone, in press).

Pink (2009) expertly intertwines and explicates theories around relationships between senses, embodiment and place developing further the idea of fluidity and ethnographies of 'mind-body-environment.' She proposes, 'an emplacement ethnography that attends to the question of experience by accounting for the relationships between bodies, minds and materiality and sensoriality of the environment' (Pink, 2009: 25). Pink is for the most part attending to social/cultural environment in every-day post-industrial society and only marginally engages with the natural environment and the elements through brief attention to gardening in her work. So to explore how nature or place becomes part of individuals and groups' 'being' when practicing adventurous or naturebased sport, I suggest that we need to take account of recent scholarship, drawing upon ethnographic methodology but importantly embracing the natural environment and the elements.

\section{Edgework, flow, mindfulness and spirituality?}

The concept edgework developed by Lyng (1990) to analyse the boundaries of control and chaos in the social exploration of risk-taking activities has been used to explore participants' perspectives in a social context of dangerous work (Kidder, 2006; Lyng, 2004) and in adventurous activities or leisure and sport (Laurendeau, 2006; Ormod \& Wheaton, 2009; Humberstone, 2009) which are perceived to have dangerous dimensions, largely ignoring the natural environment. I do not intend to discuss this concept in any depth rather I wish to draw attention to the ways in which, whilst it mentions the significance of emotions, senses and feelings in the perceptions of participants in practice, little work has been done to explore the embodiment, senses, and practice-in-nature nexus nor how this might lead to environmental awareness and action. Kidder (2006: 34) drawing upon this concept makes the point that, "it is not only in tempting death that one can become "engrossed creatively," losing all track of time and becoming completely absorbed, but also one may become absorbed in activity practices that are less hazardous, more mundane.
Milovanovic (2005) argues that 'edgeworkers,' those practicing/working at the boundaries, may vary in their perception of being in control and some talk of embodying 'transcendental experiences.'

These transcendental experiences are also identified by participants in a variety of nature-based sport from those perceived to be high-risk through to those appearing to be low risk. High and low risk activities depend significantly on both the material; the context, place and environment, in which they take place, but also on the embodied emotions and senses of the practitioner. For example, surfing may be high risk in big waves or low risk in small off beach waves (Olivier, 2006). Those with more experience may be less fearful in any real sense whilst engaged in the activity but may still experience being 'engrossed creatively' or what has been called 'flow' (Csikzentimihalyi, 1975). This concept, flow, has been used to describe the physiological changes and sharpened awareness occurring at times of 'peak' experience or performance in sport. It has also been used to describe the state of being that participants, on occasion, experience in a variety of nature-based, adventurous sports when they identify as being 'in the zone,' 'feeling a buzz,' 'stoked,' 'feeling good,' 'at one with nature,' 'being timeless' and so forth. I have argued elsewhere that in a way the term flow may not only mask an understanding of the affective, embodied sensations, the sentience of the experience and the ways in which the body learns to move and be in the natural environment, but also, for the most part, it does not engage with the social, environmental and political (Humberstone, 2011).

Subsumed by the moment, in this state the participant loses track of time and becomes one with their equipment, the elements and the natural environment. Whilst edgework tells us something about the boundaries of control and chaos, flow names occasions at which time stands still and there is a sense of connectedness with the elements and nature. This centredness may be a time and place when the body-mind, senses, elements are in tune and represents the coming together or nexus of senses (sensoria), embodiment, physical activity practice, all coming together in focus. The embodiment of/at this nexus may spawn the becoming of 'kinetic empathy,' the affects at the junction of elements/ environment-human and non-human relations.

Unravelling adventure and nature-based practitioners' expressions of flow, emerges ideas of mindfulness, spirituality and oneness with nature. One windsurfer reported in Dant and Wheaton (2007: 11) opines, 'It's almost a spiritual thing [...] the feel good factor is so... The simple physical feeling it gives you is great.' Furthermore, narratives of nature-based or adventurous activities frequently identify transcendental or spiritual features; Taylor (2007) in surfing cultures, Atkinson (2010) in fell (cross country-mountain) running and Ralston (Ralston, 2005: 16-17) in his autobiography on solo hiking, 'A sense of mindless happiness. I think solo hiking is my own method of attaining a transcendental state, a kind of walking meditation.'

Whilst reminding the reader of the turn to the body and 
sensoria in sport sociology scholarship, Fox and Humberstone (in press) point to the predominance of Western influence and the limited attention to non-Western concepts of embodiment. Drawing upon autoethnographies of very different outdoor activities; long distance cycling and local windsurfing, they explore phenomenologically how the body 'learns' through these activities. Fox in her daily cycling, her body and mind became one, 'the balance of her bike as "instinct" and her mind and understanding of alternative life rhythms was moulded by the daily routines and bodily limits of what could be done in any one day within a particular landscape' (Fox \& Humberstone, in press). Whilst Humberstone intermittently takes to the water to windsurf on a sea near to home, for short periods of time during different weather conditions. Despite these very different practices, Fox and Humberstone (in press) drawing on sensoria scholarship and traditional logic concepts of exercise and the body argue that each of these practices,

[s]hare(s) a oneness or body-mind consciousness. A predominant commonality is the engagement of mind-body moment by moment. Windsurfing is a continual awareness and presence to the minute and subtle shifts of wind, water, and balance. Given speed and constant movement of multiple forces (wind, water, body, windsurfing board), the response of the mind-body engages states of consciousness and responsiveness beyond the capabilities of cognitive consciousness. In addition, the specific movement of the windsurfing board, the opening of senses to the environment, the vulnerability and interconnection of human body with the environment also create states of consciousness.

For both of these activities in nature, one which is repetitive and continuous and the other which is both reactive and proactive in relation to the elements and equipment, there is a sense of, on occasion, a oneness with nature, a body-mind absorption something in the sense of spirituality.

\section{Kinetic empathy and environmental justice}

Many interpretative studies around adventurous activities and nature-based sport as above indicate, on occasions, that these activities may provide processes and practices that are alternative or complementary to traditional sporting 'body pedagogics' (Mellor \& Shilling, 2010). These embodied adventurous practices in nature, whether they are perceived as high or low risk, are ambiguous and fluid and may challenge dominant sporting narratives of body/mind separation and potentially afford pedagogic processes or 'techniques of the body' fostering a form of shared 'kinetic empathy.' Kinetic empathy, Thrift (2008) argues, may stimulate and engender the cultural turn to the affective and sensuous. Thorpe and Rinehart (2010: 1268) interrogate cultural geographer Thrift's social theory with the intention of checking its potentiality 'for shedding new light on the lived, affective and affecting experiences of participants in contemporary sport and physical cultures.' Drawing upon Thrift's conceptualisations, they examine the implications of the concepts 'politics of hope' and 'politics of affect' for making sense of 'social justice movements (e.g., health, educational, environmental, anti-violence)' that they evidence are flourishing within what they term 'alternative sport' cultures. Evidence suggests that social and environmental justice movements, movements which build upon environmental awareness, are frequently spawned by people's involvement in nature-based adventure sport (see Thorpe \& Rinehart, 2010; Humberstone, 2011; Taylor \& Wheaton, 2007).

We can see the material evidence of some of these movements such as SurfAid International, a non-profit humanitarian organisation dedicated to 'improving the health and well-being of people living in isolated regions connected to us through surfing' (Thorpe \& Rinehart, 2010: 1280). Taylor (2007) talks of the development of environmentalism in the surfing communities of North America and Wheaton (2007) discusses the environmental activism of the Surfers Against Sewage organisation which emerged from surfers' and windsurfers' concern for sea pollution in $\mathrm{UK}^{3}$.

As an ethnographer, I am interested in how and if individuals and groups' in nature-based physical cultures 'learn' through their bodies this 'kinetic empathy;' the significance of the process of mindfulness or spiritual experience and how this is/can be shared and understood. As Anderson asks, 'Can only a surfer know the feeling?' Anderson (2012) develops an argument to explore and make available to the reader /observer his attempt to 'share' this sensory and emotional experience of surfing through visual and audio presentations. ${ }^{4}$ I will not discuss his argument here. Suffice it to say that this 'paradox of representation' is partly attended to through providing creative tension through creative writing and imaginings as well as visual images.

Outdoor educator and environmentalist Nicol (2013: 4), who undertook an unusual solo kayak journey around part of Scotland, argues that

\footnotetext{
${ }^{3}$ Interestingly, from my little knowledge it seems that adventure tourism in the small town in Brazil, Brotas, claiming to be the adventure capital, emerged from a desire to maintain the natural environment around Brotas and claims to be a leader in the environmental movement. ' 10 years ago, a group of local citizens of Brotas got together and made a plan - to attract tourists to the area but keep its natural beauty from being endangered. Brotas leads the way in environmental tourism in the area, and has a reputation all over Brazil for being a trend-setter in environmentally sustainable ecotourism.' (Accessed 11-04-13 http:// www.brotas.info/brotas-facts.html)
}

${ }^{4}$ See 'Can only a surfer know the feeling' http://www.spatial manifesto.com/research-projects/surfing-places/affective-landscapes 
'Through writing I wanted to share these experiences to explore the educational potential where mind, body and world come together in outdoor places. For the journey to be more than a self-indulgent exercise I had to find a suitable means of capturing and analysing data.'

Attempting to balance this paradox in nature-based physical culture, Humberstone, 2011; Fox and Humberstone, (in press); Fox, Humberstone, and Dubnewick (in press) have mindfully and corporeally engaged in autoethnographic and duoethnographic research and through creative writing and poetic text endeavoured to share these feelings and sensations.

\section{Concluding remarks}

I asked in this paper as Downey, 'How does the body come to "know"? and what is it about "our relationship to each other, space, time and place (that) are mediated by our movement through,' the natural environment when we engage in adventurous activities that may promote an environmental awareness and action?

I suggest that there is in many cases a oneness with nature, a body-mind absorption something in the sense of spirituality, in which practitioners experience transcendental experiences that are embodied when the senses and body nexus are in tune which may foster a greater shared environmental awareness. I have also pointed to this shared experience creating a 'kinetic empathy' which may be realised as environmental action. Finally I draw attention to the paradox of (re)-presenting these sensorial experiences and ask us to consider how we interconnect with the environment when we participate in adventurous and nature-based activities.

\section{References}

Aall, C. Klepp, I. G. Agnes, Engeset, B. Skuland, S. E., \& Støa, E. (2011): Leisure and sustainable development in Norway: part of the solution and the problem, Leisure Studies, 30 (4), 453476.

Allen-Collinson, J. (2011). Feminist phenomenology and the woman in the running body. Sports, Ethics, Philosophy, 5 (3), 297-313.

Allen-Collinson, J., \& Hockey, J. (2011). Feeling the way: Notes towards a haptic phenomenology of distance running and scuba diving. International Review for the Sociology of Sport, 46, 330-345.

Anderson, J. (2012). Can only a surfer know the feeling? A film created for the Affective Landscapes conference in the University of Derby, UK, May 2012 (http://www.spatial manifesto.com/research-projects/surfing-places/affectivelandscapes; accessed 02-04-2013).

Atkinson, M. (2010). Entering scapeland: Yoga, fell and postsport physical cultures. Sport in Society, 13 (7), 1249-1267.

Carnicelli-Filho, S., Schwartz, G. M., \& Klein Tahara, T. (2010). Fear and adventure tourism in Brazil. Tourism Management, 31, 953-956.
Cresswell, T. (2006). On the Move: Mobility in the Modern Western World. London: Routledge.

Csikzentimihalyi, M. (1975). Beyond boredom and anxiety: Experiencing flow in work and play. San Francisco, CA: Jossey Bass.

Church, A., \& Ravenscroft, N. (2011). Politics, research and the natural environment: the lifeworlds of water-based sport and recreation in Wales. Leisure Studies, 30 (4),387-405.

Dant, T., \& Wheaton, B. (2007). An extreme form of material or embodied interaction. Anthropology Today, 23 (6), 8-12.

Denison, J., \& Markula, P. (2003) (Eds.). 'Moving writing': Crafting movement and sport research. New York: Peter Lang.

Downey, G. (2005). Learning Capoeira: Lessons in cunning from an Afro-Brazilian art. NewYork: Oxford University Press.

Downey, G. (2007). 'Seeing with a 'sideways glance:' visuomotor "knowing" and the plasticity of perceptions.' In M. Harris (Ed.). Ways of Knowing: New Approaches in the Anthropology of Experience and Learning. Oxford: Berghahn.

Ellis, C., \& Bochner, A. (2000) Autoethnography, Personal Narrative, Reflexivity. Researcher as Subject, in N. K. Denzin \& Y.S. Lincoln (Eds). Handbook of Qualitative Research. Thousand Oaks, CA: Sage.

Evers, C. (2004). Men who surf. Cultural Studies Review, 10 (1), 27-41.

Evers, C. (2009). The point: Surfing, geography and a sensual life of men and masculinity on the gold coast, Australia. Social and Cultural Geography, 10 (8), 893-908.

Fincham, B., McGuinness, M., \& Murray, L. (Eds) (2010). Introduction. In B. Fincham, M. McGuinness and L. Murray (Eds), Mobile Methodologies (pp.1-10). Basingstoke, UK: Palgrave, Macmillan.

Fox, K., \& Humberstone, B. (2013) Embodiment, Mindfulness and leisure. In L. Such (Ed.) Education, culture and justice: leisure theory and insight. LSA Publication No. 125. Eastbourne: Leisure Studies Association. (in press)

Fox, K.M., Humberstone, B., \& Dubnewick, M. (in press). Cycling into Sensoria: Embodiment, Leisure and Tourism. Tourism Review International.

Grosz, E., \& Probyn, E. (Eds.). (1995). Sexy bodies: The strange carnalities offeminism. London: Routledge.

Hockey, J. (2006). Sensing the run: The senses and distance running. Senses and Society, 1 (2), 183-202.

Hockey, J., \& Allen Collinson, C. (2007). Grasping the phenomenology of sporting bodies. International Review for Sociology of Sport, 42 (2), 115-131.

Howes, D. (1991). Sense and non-sense in contemporary ethnographic practice and theory. Culture, 11 (2), 65-76.

Howes, D. (Ed.). (2005). Empire of the senses. London: Berg.

Humberstone, B. (2009). "Inside/outside the Western 'Bubble': The nexus of adventure, adventure sports and perceptions of risk in UK and Mauritius." In J. Ormrod and B. Wheaton (Eds.) "On the Edge: Leisure, Consumption and the Representation of Adventure Sports" (pp. 97-112). Eastbourne: Leisure Studies Association (LSA) Publication No. 104.

Humberstone, B. (2010). Engagements with nature: Ageing and windsurfing. In B. Watson and J. Harpin (Eds.). Identities, cultures and voices in leisure and sport (pp. 159-169). Eastbourne: Leisure Studies Association (LSA) Publication No. 116.

Humberstone, B. (2011). Embodiment and social and environmental action in nature-based sport: Spiritual Spaces, Special Issue-Leisure and the politics of the environment. Journal of Leisure Studies 30 (4) 495-512.

Humberstone, B. (2013). Embodiment, Mindfulness and leisure. 
In L. Such (Ed.) Education, culture and justice: leisure theory and insight. LSA Publication No. 125. Eastbourne: Leisure Studies Association. (in press)

Kidder , J. (2006). "It's the Job that I Love:" Bike Messengers and Edgework. Sociological Forum, 21 (1), March 2006.

Laurendeau, J. (2006). He didn't go in doing a skydive: Sustaining the illusion of control in an edgework activity. Sociological Perspectives, 49, (4): 583-605.

Lyng, S. (1990). Edgework: A social psychological analysis of voluntary risk taking. American Journal of Sociology, 35 (1), $851-886$

Lyng, S. (2004). Crime, edgework and corporeal transaction. Theoretical Criminology, 8 (3), 359-375.

Mansfield, L., \& Wheaton, B. (2011): Leisure and the politics of the environment. Leisure Studies, 30 (4), 383-386.

Mellor, P.A., \& Shilling, C. (2010). Body pedagogics and the religious habitus: A new direction for the sociological study of religion. Religion, 40, 27-38.

Merleau-Ponty, M. (2002[1962]). The Phenomenology of Perception. London; Routledge.

Milovanovic, D. (2005). "Edgework: A Subjective and Structural Model of Negotiating Boundaries." In S. Lyng (Ed). Edgework: The Sociology of Risk-Taking (pp. 17-49). New York: Routledge.

Merchant, S. (2011). The body and the senses: Visual methods, videography and the submarine sensorium. Body \& Society, $17,53-72$.

Nicol, R. (2013) Returning to the richness of experience: is autoethnography a useful approach for outdoor educators in promoting pro-environmental behaviour? Journal of Adventure Education and Outdoor Learning, 13 (1), 3-17.

Olivier, S. (2006). 'Moral Dilemmas of Participation in Dangerous Leisure Activities.' Leisure Studies, 25 (1), 95-109.

Ormrod, J., \& Wheaton, B. (2009). On the edge. Leisure, consumption and the representation of adventure of sports. Eastborne: Leisure Studies Association.

Pink, S. (2009). Doing Sensory Ethnography. London: Sage.

Ralston, A. (2005). Between a rock and a hard place. London: Pocket Books.

Reed-Danahay, D. (1997). Auto/ethnography. New York: Berg.

Shilling, C. (1994). The body in social theory. London: Sage.

Shilling, C. (2005). The body in culture, technology and society. London: Sage.

Sparkes, A. (2002). Telling tales in sport and physical activity: A qualitative journey. Leeds: Human Kinetics.

Sparkes, A. (2004). Reflections on an embodied sport and exercise psychology. In R. Stelter and K. Roessler (Eds.). New approaches to exercise and sport psychology (pp. 31-54). Oxford: Meyer \& Meyer Sport.

Sparkes, A. (2009). Ethnography and the senses: Challenges and possibilities. Qualitative. Research in Sport and Exercise, 1(1), 21-35.

Sparkes, A. (2010). Performing the ageing body and the importance of place. Some autoethnographic moments. In B. Humberstone (Ed.). Third age and leisure research: Principles and practice. Eastbourne: Leisure Studies Association Publication (LSA) No. 108.

Sparkes, A., \& Smith, B. (2012). Embodied Research Methodologies and seeking the senses in sport and physical culture: A fleshing out of problems and possibilities. Qualitative Research on Sport and Physical Culture Research in the Sociology of Sport, 6, $167-190$

Stoddart, M.C.J. (2011). Leisure, nature and environmental move- ments in the mass media: comparing Jumbo Pass and the Tobeatic Wilderness Area, Canada. Leisure Studies, 30 (4), 407-422.

Swain, M. (2004). (Dis)embodied experience and power dynamics in tourism research. In J. Phillimore and L. Goodson (Eds.). Qualitative Research in Tourism, Ontology, Epistemologies and Methodologies (pp. 102-118). London: Routledge.

Taylor, B. (2007). Surfing into spirituality and a new, aquatic nature religion. Journal of the American Academy of Religion, 75(4), 923-951.

Thorpe, H., \& Rinehart, R. (2010). 'Alternative sport and affect: non-representational theory examined.' Sport in Society, 13 (7), 1268-1291.

Thrift, N. (2000). Non-representational theory. In R.J. Johnston, D. Gregory, G. Pratt, and M. Watt (Eds.). The dictionary of human geography (4th ed.). Oxford: Blackwell.

Thrift, N. (2006). Space. Theory, Culture and Society, 23 (23), 139-155.

Thrift, N. (2008). Non-representational theory: Space, politics, affect. London: Routledge.

Urry, J. (2007). Mobilities. Cambridge: Polity Press.

Wheaton, B. (2007). Identity, politics, and the beach: Environmental activism in surfers against sewage. Leisure Studies, 26 (3), 279-302.

\section{Author's note}

\section{Acknowledgements}

I would like to thank the director and organisers of 2013 International Congress of Physical Activity and Human Movement Sciences (VIII CIEFMH-XIV SPEF) in Rio Claro, State of São Paulo, Brazil for their generous invitation to me to be a guest speaker at the congress. My presentation is based, in part, on this paper.

\section{Correspondence}

Barbara Humberstone $\mathrm{PhD}$

Professor Sociology of Sport \& Outdoor Education

Buckinghamshire New University, Department Sport Management Queen Alexandra Rd

High Wycombe

Bucks HP11 2JZ

Email: Barbara.Humberstone@bucks.ac.uk

Declaration of Conflicting Interests: The author declared no conflicts of interest with respect to the research, authorship, and/or publication of this article.

Manuscript received on March 30, 2013

Manuscript accepted on May 10, 2013 